Article

\title{
Zinc Concentration and Distribution in Vineyard Soils and Grapevine Leaves from Valdepeñas Designation of Origin (Central Spain)
}

\author{
Francisco Jesús García-Navarro ${ }^{1, *} \mathbb{C}$, Raimundo Jiménez-Ballesta ${ }^{2}{ }^{\mathbb{D}}$, Jesus Garcia-Pradas ${ }^{1}$, Jose A. Amoros ${ }^{1} \mathbb{D}$ \\ Caridad Perez de los Reyes ${ }^{1}\left[\right.$ and Sandra Bravo ${ }^{1}$ (i) \\ 1 Hight Technical School Agricultural Engineers of Ciudad Real, University of Castilla-La Mancha, \\ 13003 Ciudad Real, Spain; jesus.garciapradas@uclm.es (J.G.-P.); joseangel.amoros@uclm.es (J.A.A.); \\ caridad.perez@uclm.es (C.P.d.1.R.); sandra.bravo@uclm.es (S.B.) \\ 2 Department of Geology and Geoschemistry, Autónoma University of Madrid, 28049 Madrid, Spain; \\ raimundo.jimenez@uam.es \\ * Correspondence: fcojesus.garcia@uclm.es
}

check for updates

Citation: García-Navarro, F.J.; Jiménez-Ballesta, R.; Garcia-Pradas, J.; Amoros, J.A.; Perez de los Reyes, C.; Bravo, S. Zinc Concentration and Distribution in Vineyard Soils and Grapevine Leaves from Valdepeñas Designation of Origin (Central Spain). Sustainability 2021, 13, 7390 . https://doi.org/10.3390/ su13137390

Academic Editors: Jose Navarro

Pedreño and Manuel

Miguel Jordan-Vidal

Received: 25 May 2021

Accepted: 28 June 2021

Published: 1 July 2021

Publisher's Note: MDPI stays neutral with regard to jurisdictional claims in published maps and institutional affiliations.

Copyright: (c) 2021 by the authors. Licensee MDPI, Basel, Switzerland. This article is an open access article distributed under the terms and conditions of the Creative Commons Attribution (CC BY) license (https:// creativecommons.org/licenses/by/ $4.0 /)$.
Abstract: (1) Background: The purpose of this study was to investigate zinc contents in leaves and soils of the Valdepeñas Protected Designation of Origin (PDO), situated in central Spain. Zn distribution maps of leaves and soils were obtained. (2) Methods: Ninety soil profiles were described, sampled and analyzed. Furthermore, vineyard leaves were collected randomly in each of the analyzed soil vineyard profiles. Soil and leaf samples were analyzed by X-ray fluorescence. (3) Results: The mean total $\mathrm{Zn}$ concentrations in vineyard soils were in the range of $16.2-153.7 \mathrm{mg} \cdot \mathrm{kg}^{-1}$, with a mean of $47.5 \mathrm{mg} \cdot \mathrm{kg}^{-1}$. The obtained values above the $95 \mathrm{th}$ percentile (between 81.3 and $153.7 \mathrm{mg} \cdot \mathrm{kg}^{-1}$ ) could be affected by different parent materials or $\mathrm{Zn}$ agricultural treatments in vineyards. Contents in different soils follow the order Entisol > Alfisol > Inceptisol. The average Zn content value in leaves was $23.8 \mathrm{mg} \cdot \mathrm{kg}^{-1}$ and oscillated between 11.5 and $93.3 \mathrm{mg} \cdot \mathrm{kg}^{-1}$; minor differences were detected between soil types, with the highest value in plants grown on soils without carbonates. (4) Conclusions: The obtained values are optimal for vine cultivation. The bioaccumulation factors in leaves were lower than unity (0.24-0.53 range). This means that the $\mathrm{Zn}$ bioaccumulation process is relatively low in the soil-grapevine system. This study serves as a reference to identify areas that present $\mathrm{Zn}$ deficiencies or risk of contamination.

Keywords: vineyard soils and leaves; Zn content; Zn distribution; plant growth; fertilizers; La Mancha

\section{Introduction}

Soil is a key factor of the natural environment that contributes to vine crops in a complex way [1]. Accordingly, soil influences vine development through mineral supply [2]. To complete its life cycle, vine needs 15 nutritional elements, of which nine are macroelements (C, O, H, Ca, N, K, P, Mg and S), while the other six (Fe, $\mathrm{Zn}, \mathrm{B}, \mathrm{Mn}, \mathrm{Cu}$ and $\mathrm{Mo}$ ) are trace elements [3]. Other elements such as $\mathrm{Si}, \mathrm{Al}, \mathrm{Cl}$ and $\mathrm{Na}$ are also present in vine organs, but do not seem to be essential, as Wild [4] reports.

Agronomically speaking, zinc (Zn) is a fundamental and relevant micronutrient for plants because it plays a key role in several biological processes. It is involved in chlorophyll formation and is an essential component of certain plant enzymes, e.g., in auxin formation. Presently, Zn is recognized as a vital component in several dehydrogenases, proteinases, $\mathrm{Zn}$ containing enzymes, Zn-activated enzymes, protein synthesis, carbohydrate metabolism, tryptophan and indoleacetic acid synthesis, membrane integrity and lipid peroxidation [3].

Zinc is a metallic element whose natural concentration in soil depends on its concentration in parent materials. Zn occurs in the Earth's crust at low concentrations. In England, $\mathrm{Zn}$ lies between 1.5 and $264.0 \mathrm{mg} \cdot \mathrm{kg}^{-1}$ according to Holmgren et al. [5], and its average 
value is $53 \mathrm{mg} \cdot \mathrm{kg}^{-1}$. Alloway [6] shows $\mathrm{Zn}$ contents for various parent materials (in $\mathrm{mg} \cdot \mathrm{kg}^{-1}$ ): crust 51 , granite 50 , basalt 100 , sandstone 20 , shale 100 , limestone 40 . Sparks [7] indicates a mean value of $60 \mathrm{mg} \cdot \mathrm{kg}^{-1}$.

The average $\mathrm{Zn}$ concentration in soils recorded worldwide ranges from 10 to $100 \mathrm{mg} \cdot \mathrm{kg}^{-1}$. Guideline values are defined on the basis of either ecological risks (e) or health risks (t), according to Tóth et al. [8]. The MEF [9] states that the threshold and guideline values for $\mathrm{Zn}$ in soil are as follows (in $\mathrm{mg} \cdot \mathrm{kg}^{-1}$ ): threshold value 200, lower guideline value 250, higher guideline value 400 . Micó et al. [10] propose a value of $83 \mathrm{mg} \cdot \mathrm{kg}^{-1}$ as the baseline $\mathrm{Zn}$ value in a Mediterranean region.

Normally, Zn deficiencies appear in very acidic or very calcareous soils, in which case smaller bunches form and internodes shorten. Large amounts of $\mathrm{Zn}$, which derive mostly from human activities, can be toxic to flora, fauna and humans. In plants, excess $\mathrm{Zn}$ causes morphological, biochemical and physiological disorders.

Zinc can derive from natural sources, such as rock weathering, desert and sea mist, gas emissions and volcanic particles [11,12]. In agroecosystems, some phytosanitary products are widely used to control fungi, bacteria, invertebrates and algae. In this way, a source of $\mathrm{Zn}$ in grapevine is phytosanitary products applied to control diseases, which can lead to $\mathrm{Zn}$ accumulation and changes in the distribution of the fractions of these elements in soil.

Viticulture represents one of the most important agricultural activities in La Mancha (central Spain). Therefore, determining total zinc content in vineyard soils is an essential step in assessing hazards for vital soil roles in the vineyard ecosystem.

For all these reasons, reliable information on $\mathrm{Zn}$ concentrations in vineyard soils is critical. In short, this study focuses on the Valdepeñas PDO and poses the following questions: are $\mathrm{Zn}$ contents at the same level in vineyard soils when soil types differ? Are $\mathrm{Zn}$ contents different in ploughed and subsoil layers in soil profiles? What is the Zn content in vine leaves? Are Zn contents at the same level in the Valdepeñas PDO region compared with the rest of the world?

\section{Materials and Methods}

\subsection{Study Area and Sampling}

Research was carried out in a wine-producing zone located in the southern subplateau of the Iberian Peninsula, La Mancha (Figure 1), specifically in the Valdepeñas PDO (Protected Designation of Origin; coordinates: $38^{\circ} 45^{\prime} 59^{\prime \prime} \mathrm{N}$ and $3^{\circ} 23^{\prime} 59^{\prime \prime} \mathrm{O}$ ). The area is made up of a large plain (predominantly a flat plateau) on which some mountain ranges and their associated reliefs stand out (see Figure 2). Soils develop mainly on calcareous materials consisting of limy marl, limestone and sandstone, and on other rocks such as quarcites, shales, schists, a few granitoids and volcanic materials. The climate in this region is semiarid. The average annual rainfall is $450 \mathrm{~mm}$, and the annual mean temperature is $12-14^{\circ} \mathrm{C}$, ranging from $6{ }^{\circ} \mathrm{C}$ (January) to $25^{\circ} \mathrm{C}$ (July).

\section{Spain \\ Valdepeñas P.D.O.}

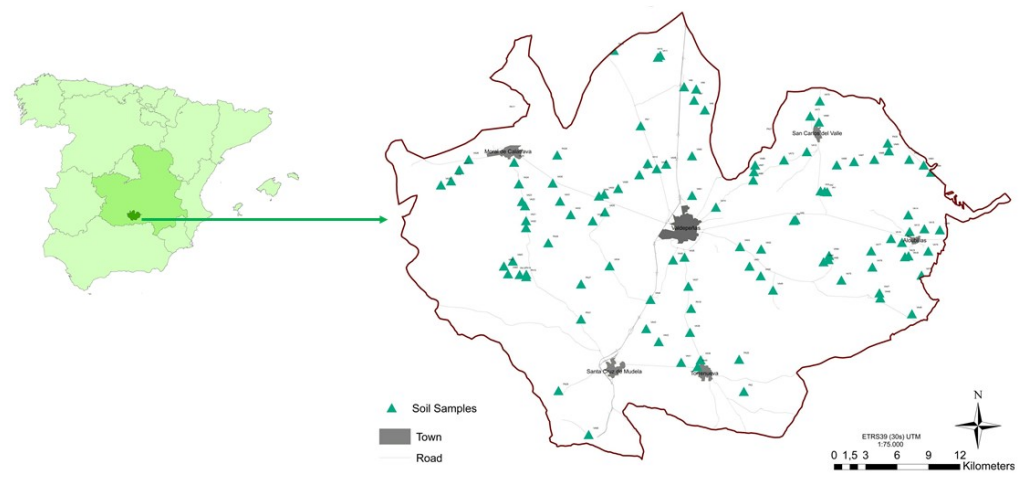

Figure 1. Location area and soil/leaf sampling locations (sites). 

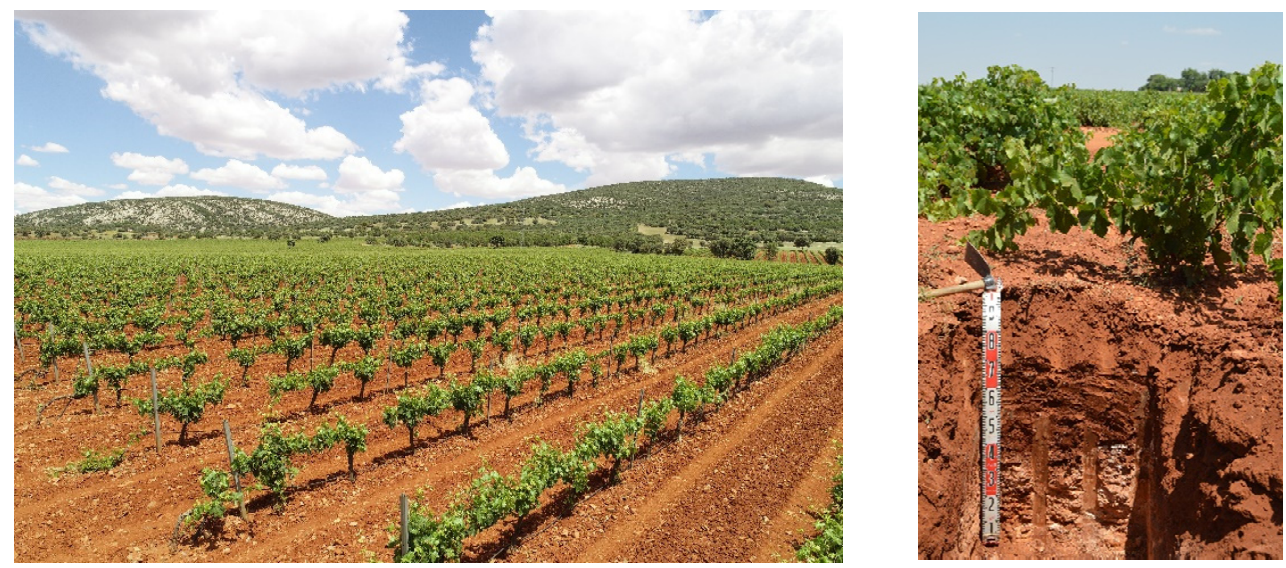

Figure 2. Characteristic red soil and landscape vineyard of the Valdepeñas PDO.

The vineyard samples herein used were collected during a project undertaken in the Valdepeñas PDO in 2018 and 2019. A soil sampling network was set up to cover the majority of the Valdepeñas territory. Ninety soil profiles were described at the same time and were sampled by considering the vineyard macromorphologic soil characteristics and geomorphological positions, among other features. García-Navarro et al. [13] conclude that the soil groups are Luvisols, Calcisols, Cambisols, Regosols and Leptosols according to FAO-UNESCO-ISSS [14], while identified soil orders are mainly Alfisols, Inceptisols and Entisols according to Soil Taxonomy [15]. Soil samples were collected from each horizon of the 90 selected profiles. Each sampling location (longitudes, latitudes, and altitudes) was identified in the field using a portable global positioning system (GPS). Finally, for leaf sampling, approximately 20 mature leaves were collected randomly in each one of the analyzed soil vineyard profiles. A schematic diagram of the research sampling locations appears in Figure 1; a typical red soil in its landscape appears in Figure 2.

\subsection{Laboratory Analysis}

Soil and leaf samples collected for analysis are representative of the whole sampled area. Soil samples were dried at room temperature and then sieved at $2 \mathrm{~mm}$ to analyze the fine soil fraction. Fresh green and healthy grapevine leaves were placed on cellulose filter paper in a well-aerated room and were air-dried at room temperature.

For $\mathrm{Zn}$ determinations, in a first step samples were ground in an agate mortar, and then pearls with lithium borate formed. Finally, pearls were analyzed by $\mathrm{X}$-ray fluorescence using a Philips PW 2404 spectrophotometer. The precision and accuracy of the results were checked by measuring standard reference materials (SRM). Quality control was achieved by analysis of triplicate samples and certified reference materials (NIST 2710 and CRM 039). Quantitative calculations were made through the fundamental parameters method.

\subsection{Statistical and Geostatistical Methods}

For statistical analysis, data from different horizons were treated. Statistical descriptors (mean, standard deviation, maximum and minimum) were calculated using the IBM software SPSS version 24.0. Zinc spatial variability was obtained by processing data using ArcGis v.10.3, under license for UCLM. The chosen method was processed by the IDW (weighted inverse distance) algorithm, which gives satisfactory precision for the number of samples, and the calculations were carried out with all the points in the database.

\section{Results}

The total Zn concentrations in the Valdepeñas PDO vineyard soils and leaves are provided in Tables 1 and 2. The bioaccumulation factor (BAC calculated as the ratio between the concentration of elements in the plant and soil) also appears in Table 2. The total $\mathrm{Zn}$ concentration in the vineyard soils ranged from 16.2 to $153.7 \mathrm{mg} \cdot \mathrm{kg}^{-1}$, and the 
total zinc mean was $55.1 \mathrm{mg} \cdot \mathrm{kg}^{-1}$. These results are lower than those obtained by JimenezBallesta et al. [16], taken as the reference value for Castilla-La Mancha $\left(86.5 \mathrm{mg} \cdot \mathrm{kg}^{-1}\right)$, where Valdepeñas is located. The obtained values are higher than those recorded by Bravo et al. [17] for Castilla-La Mancha agricultural soils. The total Zn content in the vineyard soils showed no significant differences in relation to soil depth. The calcareous parent material characteristics, geomorphology and landscape features very much contribute to $\mathrm{Zn}$ distribution variability. A whole range of starting materials can be combined as "calcareous carbonate sedimentary material" according to Neuendorf et al. [18] and Schoeneberger et al. [19].

Table 1. Statistical indicators of $\mathrm{Zn}$ contents $\left(\mathrm{mg} \cdot \mathrm{kg}^{-1}\right)$ per soil type orders in vineyard soils.

\begin{tabular}{|c|c|c|c|c|c|c|c|}
\hline \multirow{2}{*}{ Soil Type } & \multirow{2}{*}{$\mathbf{n}$} & \multicolumn{2}{|c|}{ Percentile } & \multirow{2}{*}{ Maximum } & \multirow{2}{*}{ Minimum } & \multirow{2}{*}{ Mean } & \multirow{2}{*}{ St } \\
\hline & & 50 & 95 & & & & \\
\hline \multicolumn{8}{|l|}{ All soils } \\
\hline Plough layer (Ap) & 80 & 54.4 & 91.9 & 126.3 & 27.3 & 47.6 & 20.3 \\
\hline Subsoil (B or C) & 73 & 49.5 & 86.9 & 153.7 & 16.2 & 52.7 & 24.7 \\
\hline \multicolumn{8}{|l|}{ Alfisol } \\
\hline Plough layer (Ap) & 35 & 58.3 & 98.6 & 125.8 & 35.8 & 61.2 & 18.8 \\
\hline Subsoil (B or C) & 35 & 56.7 & 81.2 & 153.7 & 34.1 & 61.4 & 20.6 \\
\hline \multicolumn{8}{|l|}{ Inceptisol } \\
\hline Plough layer (Ap) & 39 & 43.1 & 95.3 & 126.3 & 27.3 & 52.2 & 20.1 \\
\hline Subsoil (B or C) & 33 & 36.6 & 79.8 & 89.6 & 16.2 & 38.3 & 19.1 \\
\hline \multicolumn{8}{|l|}{ Entisol } \\
\hline Plough layer (Ap) & 6 & 71.5 & 97.9 & 102.3 & 41.9 & 70.9 & 22.6 \\
\hline Subsoil (B or C) & 5 & 83.9 & 118.6 & 123.2 & 58.3 & 86.8 & 25.9 \\
\hline \multicolumn{8}{|l|}{ With $\mathrm{CaCO}_{3}$} \\
\hline Plough layer (Ap) & 70 & 53.3 & 98.5 & 126.3 & 27.3 & 56.2 & 20.5 \\
\hline Subsoil (B or C) & 63 & 46.8 & 81.3 & 153.7 & 16.2 & 49.1 & 23.2 \\
\hline \multicolumn{8}{|l|}{ Without $\mathrm{CaCO}_{3}$} \\
\hline Plough layer (Ap) & 10 & 74.9 & 95.8 & 102.3 & 40.8 & 71.6 & 19.4 \\
\hline Subsoil (B or C) & 10 & 74.1 & 112.9 & 123.2 & 48,0 & 77.4 & 21.4 \\
\hline Bravo et al., 2019 & & 37.6 & & 225.0 & 5.0 & 43.5 & \\
\hline Reiman et al., 2014 & & 61.0 & 129.9 & 413.0 & 3.0 & 84.7 & \\
\hline
\end{tabular}

Plants' ability to take up nutrients from soil can be measured by the bioaccumulation factor (BAC). Table 2 provides the calculated BAC values. When comparing these data with those contributed worldwide for different plants [20], three groups of values were found: higher than 1 , from 0.1 to 1 , and from 0.01 to 1 . These groups correspond to a higher BAC value with better relative plant uptake of elements.

According to Wild [4], the normal content in rocks is $70 \mathrm{mg} \cdot \mathrm{kg}^{-1}$ and in soil $60 \mathrm{mg} \cdot \mathrm{kg}^{-1}$, and values are sometimes higher than $200 \mathrm{mg} \mathrm{kg}^{-1}$. The values for soil contents generally range from 1 to $100 \mathrm{mg} \cdot \mathrm{kg}^{-1}$ worldwide, depending on the soil parent material nature [21]. The baseline $\mathrm{Zn}$ value in agricultural soils in a European Mediterranean region is $83 \mathrm{mg} \cdot \mathrm{kg}^{-1}$ [10]. 
Table 2. Statistical indicators of $\mathrm{Zn}$ contents $\left(\mathrm{mg} \cdot \mathrm{kg}^{-1}\right)$ in grapevine leaves. BAC values are also provided.

\begin{tabular}{|c|c|c|c|c|c|c|c|c|c|c|}
\hline \multirow{3}{*}{$\begin{array}{l}\text { Leaves } \\
\text { All soils }\end{array}$} & \multirow{3}{*}{$\begin{array}{l}\mathbf{n} \\
60\end{array}$} & \multicolumn{2}{|c|}{ Percentile } & \multirow{3}{*}{$\begin{array}{l}\text { Max. } \\
93.3\end{array}$} & \multirow{3}{*}{$\begin{array}{c}\text { Min. } \\
11.5\end{array}$} & \multirow{2}{*}{\multicolumn{2}{|c|}{ Mean (a) }} & \multirow{3}{*}{$\begin{array}{c}\text { St } \\
12.9\end{array}$} & \multirow{2}{*}{\multicolumn{2}{|c|}{ BAC (b) }} \\
\hline & & \multirow{2}{*}{$\begin{array}{c}50 \\
20.5\end{array}$} & \multirow{2}{*}{$\begin{array}{c}95 \\
40.0\end{array}$} & & & & & & & \\
\hline & & & & & & 23.8 & Optimal & & 0.43 & Adequate \\
\hline Alfisol & 32 & 20.3 & 37.8 & 40.0 & 11.6 & 22.8 & Optimal & 8.0 & 0.37 & Adequate \\
\hline Inceptisol & 33 & 18.8 & 50.2 & 93.3 & 11.5 & 23.8 & Optimal & 18.8 & 0.53 & Adequate \\
\hline Entisol & 4 & 17.8 & 26.4 & 27.4 & 12.0 & 17.8 & Optimal & 6.9 & 0.24 & Low-marginal \\
\hline Without $\mathrm{CaCO}_{3}$ & 60 & 20.6 & 40.1 & 93.3 & 11.5 & 23.8 & Optimal & 12.9 & 0.24 & Low-marginal \\
\hline With $\mathrm{CaCO}_{3}$ & 9 & 18.5 & 26.4 & 29.8 & 11.6 & 18.1 & Optimal & 5.5 & 0.45 & Adequate \\
\hline
\end{tabular}

(a) Low <14/Optimal 14-23/High > 23 [22]. (b) < 15 deficient/15-25 low to marginal/26-150 adequate/450 high to excessive [23].

\section{Discussion}

Compared with the data in the literature, the $\mathrm{Zn}$ values obtained in Valdepeñas vineyard soils are higher in some soils than the world soil average of $50 \mathrm{mg} \cdot \mathrm{kg}^{-1}$ [24]. However, they are similar to those reported by Huzum et al. [25] in Romania (between 43.1 and $103 \mathrm{mg} \cdot \mathrm{kg}^{-1}$, with an average of $73.9 \mathrm{mg} \cdot \mathrm{kg}^{-1}$ ). Our values are also similar to those obtained by Peris et al. [26] in Castellón, Spain $\left(76.8 \mathrm{mg} \cdot \mathrm{kg}^{-1}\right)$. The $\mathrm{Zn}$ values reported in NW Romania are between 54.58 and $78.25 \mathrm{mg} \cdot \mathrm{kg}^{-1}$, with an average of $69.4 \mathrm{mg} \cdot \mathrm{kg}^{-1}$ [27]. In polluted vineyards in Plovdiv (Bulgaria), Angelova et al. [28] report $249 \mathrm{mg} \cdot \mathrm{kg}^{-1}$ in the $0-10 \mathrm{~cm}$ layer in vineyard soils, and $73 \mathrm{mg} \cdot \mathrm{kg}^{-1}$ in non-polluted vineyards. In La Rioja (Spain), Iñigo et al. [29] state that vineyard soils have Zn contents of $9.05-125.67 \mathrm{mg} \mathrm{kg}^{-1}$.

The total $\mathrm{Zn}$ contents in Valdepeñas PDO soils generally depend on parent material and pedogenic factors. The soils that develop from siliceous acid rocks, such as quarcites and schists, are mostly rich, whereas those that develop from limestones and other calcareous materials are comparatively poor in $\mathrm{Zn}$ (see Table 1).

Traditional vineyard land use can bring about changes in $\mathrm{Zn}$ soil contents because $\mathrm{Zn}$ behavior in the soil-plant system is affected. This explains why $\mathrm{Zn}$ content is higher in surface horizons sometimes, but in deep horizons at other times. Soil translocation by tillage may be the key reason for soil particle redistribution, and erosion can be particularly present at the bottom of hilly landscapes.

Indeed, some of the obtained data reveal excessive $\mathrm{Zn}$ content $\left(153.1 \mathrm{mg} \mathrm{kg}^{-1}\right.$; $\left.123.2 \mathrm{mg} \mathrm{kg}^{-1} ; 100.3 \mathrm{mg} \mathrm{kg}^{-1} ; 89.6 \mathrm{mg} \mathrm{kg}^{-1}\right)$. Zn generally enters the vineyard agroecosystem by both natural and anthropogenic processes. Among the anthropogenic processes cited in the literature, inputs from using agrochemicals, soil amendments (farm manure, biosolids, composts and industrial/municipal waste), local industrial contamination and particles from car brakes, and irrigation with contaminated water are noteworthy [30]. The world's viticulture regions are generally located in climate areas that, however, favor fungal diseases, including downy mildew (Plasmopara viticola). Today, the Valdepeñas PDO is not a region seriously affected by mildew, but it was some time ago.

As there are many owners in the Valdepeñas PDO, land fragmentation occurs and plots are subdivided into small plots. Despite owners receiving advice, some of they tend to manage each plot following their own preferences and sometimes fertilize unevenly. Therefore, it is not surprising that significant $\mathrm{Zn}$ accumulation appears in some vineyard soil profiles in the Valdepeñas PDO. This is the case of the high Zn levels found in some Alfisol profiles that develop on marls, with a value of $153.7 \mathrm{mg} \cdot \mathrm{kg}^{-1}$, and is related to management processes, such as prolonged fertilizer or pesticide-derived $\mathrm{Zn}$ uses. Therefore, $\mathrm{Zn}$ accumulates in the topsoil layer. In some old vineyards, $\mathrm{Zn}$ surpasses the background $Z n$ value several times, as reported by Mirleam et al. [31].

Zinc does not markedly interact with organic substances compared with other trace metals. Therefore, given the low organic matter content $(<2 \%$ in most samples) in Valdepeñas PDO soils [13], this effect is not feasible. A previously suggested major soil constituent for $\mathrm{Zn}$ retention in vineyards is Fe oxyhydroxides [32]. Manceau et al. [33] state 
that $\mathrm{Zn}$ is often associated with pedogenic minerals, including Fe oxyhydroxides, whereas Jacquat et al. [34] demonstrate the implications of interlayered minerals for Zn retention.

As most studied soils are red (Rhodoxeralfs in Soil Taxonomy; Rodhic or Chromic Luvisols according to FAO-ISRIC-ISSS [14]) with abundant Fe oxyhydroxides and clay minerals as a result of long exposure periods to the fersialitic weathering of old surfaces, $\mathrm{Zn}$ accumulation and inactivation are, therefore, feasible.

Whatever the origin, the bioaccumulation that results from these higher concentrations is unlikely in vine. This finding falls in line which what the ATDSR [35] states for fruit and vegetables. Thus, no $\mathrm{Zn}$ pollution exists and, hence, no food safety risk is posed. Carbonates induce $\mathrm{Zn}$ deficiency insofar as, conversely, Zn deficiency can exist in some Valdepeñas PDO soils, and it is attributed to high $\mathrm{Ca}$ and $\mathrm{CaCO}_{3}$ concentrations and a high $\mathrm{pH}[6,17]$.

After receiving $\mathrm{Zn}$ from agrochemicals or soil amendments, $\mathrm{Zn}$ accumulation occurs in topsoil and at subsoil depths of soils, specifically in Ap, Bw or Bt horizons from vineyard soils. This means that $\mathrm{Zn}$ contents can lead to a shorter and thicker vine root apex [36]. However, phosphorus can induce Zn deficiency through Zn phosphate precipitation or by $\mathrm{Zn}$ binding to phosphates absorbed in Fe oxides.

Some studies have analyzed grapevine leaf characteristics $[37,38]$ because these characteristics are very important and influence both grape characteristics and wine quality [39]. The mean concentration of $\mathrm{Zn}$ levels in aerial parts (leaves) was $23.6 \mathrm{mg} \cdot \mathrm{kg}^{-1}$. The $\mathrm{Zn}$ concentrations in the leaves in different vineyard soils were practically equal (ranging between 17.8 and $23.8 \mathrm{mg} \cdot \mathrm{kg}^{-1}$ ). Zn content in vine is taken up from soil via roots. However, many complex factors, such as soil type and chemical composition, affect $\mathrm{Zn}$ bioavailability and uptake. Thus, it is not surprising that higher Zn concentrations in soil match the higher concentrations in leaves. All these results are similar to those obtained by Bora et al. [27] in NW Romania, who report an average of $25.2 \mathrm{mg} \cdot \mathrm{kg}^{-1}$ in leaves from vine. In France, Chopin et al. [40] provide a value of $29.3 \mathrm{mg} \cdot \mathrm{kg}^{-1}$, and Vystavna et al. [41] indicate a value of $28 \mathrm{mg} \cdot \mathrm{kg}^{-1}$ in Ukraine. However, when we compared our results with the mean values of other vineyards in the La Mancha region $\left(15.2 \mathrm{mg} \cdot \mathrm{kg}^{-1}\right)$ [42], the other vineyards' results were clearly lower than those herein indicated.

Table 2 shows the results of the studied leaf analysis. According to the criteria of García-Escudero and Martín [22], the Zn concentration in the studied vine leaves is optimal.

The BAC represents a species' capacity to accumulate a compound such as $\mathrm{Zn}$. According to the criteria of White [23], the BAC is generally adequate in the Valdepeñas vineyards even if it is low to marginal (very close to adequate) in Entisols and soils without carbonates. Therefore, the results of the present study indicate that the $\mathrm{Zn}$ bioaccumulation process that occurs in the soil-grapevine system is adequate.

Figures 3 and 4 show that the $\mathrm{Zn}$ concentration is better in the subsurface horizon than in the surface horizon, respectively. Higher Zn concentrations are observed in the subsurface horizon for the area where soils classified as Alfisols are mostly found. The limits between classes were taken according to the data published by Reiman et al. [43].

From the results herein obtained, $\mathrm{Zn}$ levels are adequate. This study serves as a reference to identify areas that present $Z n$ deficiencies or risk of contamination. Notwithstanding, limestone soils may display specific Zn and Fe deficiencies [17,44]. For this reason, Zn content's effects on vine crops should not be viewed elusively by the farmers in the Valdepeñas PDO. To complement the findings of the present study, we suggest investigating more $\mathrm{Zn}$ chemical fractionation in detail. 


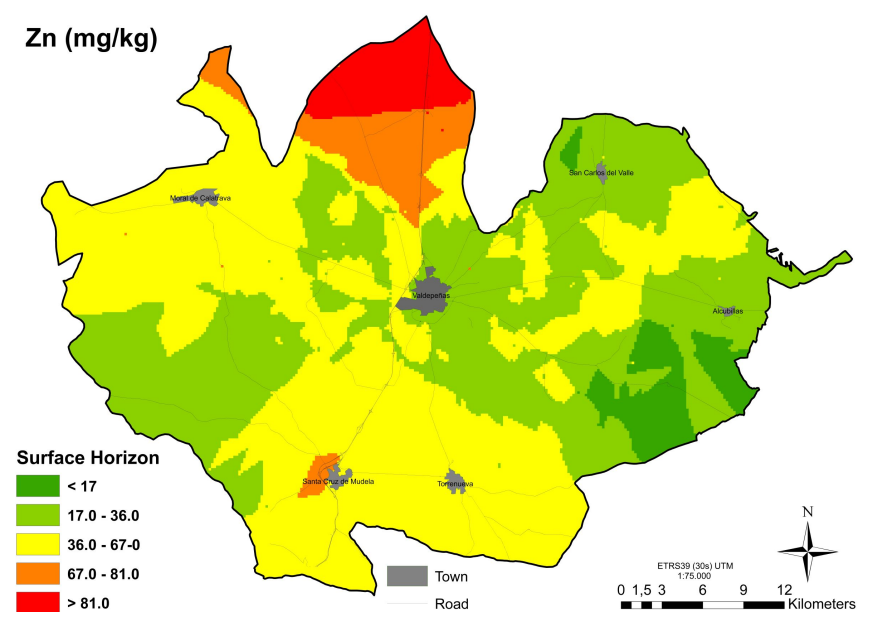

Figure 3. Spatial distribution of zinc in surface horizons in vineyard soils of Valdepeñas PDO (in $\left.\mathrm{mg} \mathrm{kg}^{-1}\right)$.

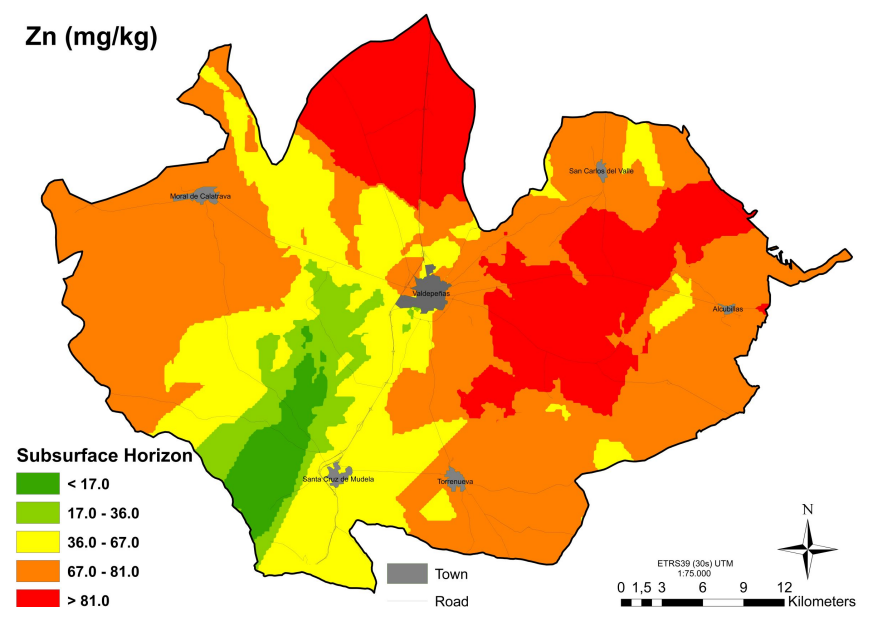

Figure 4. Spatial distribution of zinc in subsurface horizons in vineyard soils of Valdepeñas PDO (in $\mathrm{mg} \mathrm{kg}^{-1}$ ).

\section{Conclusions}

The objectives of this study were to evaluate the spatial distribution of soil $\mathrm{Zn}$ and its suitability for vineyard cultivation in the Valdpeñas PDO of Castilla-La Mancha (central Spain). According to the obtained results, the following conclusions were reached.

Geological materials and pedological processes play a key role in Zn soil occurrence, except for some specific sites where the origin of marked $\mathrm{Zn}$ soil enrichments is natural. The soil Zn concentration depends partially on soil type. The high Zn levels in some soil profiles are related to management processes, such as prolonged fertilizer or pesticidederived $\mathrm{Zn}$ uses. Selective $\mathrm{Zn}$ accumulation was found for different soil types and, despite large differences, some of them were not taken up by vine. Thus, differences were small in leaves. This means that $\mathrm{Zn}$ bioaccumulation occurs in the soil-grapevine system at adequate levels in our study area. In general, $\mathrm{Zn}$ levels are suitable despite the possibility of calcareous soils presenting a specific $Z n$ deficiency.

Author Contributions: R.J.-B., F.J.G.-N. and S.B. conceived and designed this study; F.J.G.-N., R.J.-B., S.B., C.P.d.1.R. and J.A.A. participated in the collection of soil samples; software, S.B.; formal analysis, J.G.-P.; writing—original draft preparation, R.J.-B., F.J.G.-N. and S.B. All authors have read and agreed to the published version of the manuscript.

Funding: This research was funded by "Denominación de Origen Valdepeñas" (denomination of origin), grant number UCTR180065. 
Institutional Review Board Statement: Not applicable.

Informed Consent Statement: Not applicable.

Data Availability Statement: All data are contained within the article.

Acknowledgments: The authors wish to acknowledge the financial support given by the "Denominación de Origen Valdepeñas" (Denomination of Origin). A special thanks goes to the farmers of the region.

Conflicts of Interest: The authors declare no conflict of interest.

\section{References}

1. Van Leeuwen, C.; Seguin, G. The concept of terroir in viticulture. J. Wine Res. 2006, 17, 1-10. [CrossRef]

2. Van Leeuwen, C.; de Rességuier, L. Major Soil-Related Factors in Terroir Expression and Vineyard Siting. Elements 2018, 14, 159-165. [CrossRef]

3. Marschner, P. Nutrition of Higher Plants, 3rd ed.; Elsevier Inc.: Amsterdam, The Netherlands, 2012; p. 672.

4. Wild, A. Russell 's Soil Conditions and Plant Growth, 11th ed.; Longman Scientific and Technical: Harlow, UK, $1988 ;$ p. 1014.

5. Holmgrem, G.G.S.; Meyer, M.W.; Chaney, R.L.; Daniels, R.B. Cadmiun, lead, zinc, cooper and nickel in agricultural soils of the United States of America. J. Environ. Qual. 1993, 22, 335-348. [CrossRef]

6. Alloway, B.J. Heavy Metals in Soils: Trace Metals and Metalloids in Soil and Their Bioavailability, 3rd ed.; Springer Science and Business Media: Dordrecht, The Netherlands, 2013; p. 614.

7. Sparks, D.L. Environmental Soil Chemistry, 2nd ed.; Elservier: San Diego, CA, USA, 2002; p. 368.

8. Tóth, G.; Hermann, T.; Da Silva, M.R.; Montanarella, L. Heavy metals in agricultural soils of the European Union with implications for food safety. Environ. Int. 2016, 88, 299-309. [CrossRef] [PubMed]

9. Ministry of the Environment of Finland (MEF) Government Decree on the Assessment of Soil Contamination and Remediation Needs. 214/2007. Available online: http:/ / www.finlex.fi/en/laki/kaannokset/2007/en20070214 (accessed on 19 April 2021).

10. Micó, C.; Peris, M.; Recatalá, L.; Sánchez, J. Baseline values for heavy metals in agricultural soils in a European Mediterranean region. Sci. Total Environ. 2007, 378, 13-17. [CrossRef] [PubMed]

11. Nagajyoti, P.C.; Lee, K.D.; Sreekanth, T.V.M. Heavy metals, occurrence and toxicity for plants: A review. Environ. Chem. Lett. 2010, 8, 199-216. [CrossRef]

12. Ferreira, P.A.; Brunetto, G.; Giachini, A.J.; Soares, C.R.F.S. Heavy metal remediation. In Heavy Metals Remediation Transport and Accumulation in Plants, 1st ed.; Gupta, D.K., Chatterjee, S., Eds.; Nova Sciences Publishers: New York, NY, USA, $2014 ;$ pp. 127-154.

13. García-Navarro, F.J.; Amorós, J.A.; Pérez-de-los-Reyes, C.; Bravo, S.; Jiménez-Ballesta, R. Mapa de los Suelos de la Denominación de Origen Valdepeñas; Universidad de Castilla-La Mancha: Ciudad Real, Spain, 2019.

14. FAO-ISRIC-ISSS. World Reference Base for Soil Resources. In Food and Agriculture Organization of the United Nations; FAO: Rome, Italy, 2014.

15. Soil Survey Staff. Key to Soil Taxonomy, 12nd ed.; USDA-Natural Resources, Conservation Service: Washington, DC, USA, 2014; p. 379.

16. Jiménez-Ballesta, R.; Conde Bueno, P.; Martín Rubí, J.A.; García Giménez, R. Pedogeochemical baseline content levels and soil quality reference values of trace elements in soils from the Mediterranean (Castilla-La Mancha, Spain). Cent. Eur. J. Geosci. 2010, 2, 441-454.

17. Bravo, S.; Amorós, J.A.; Pérez-De-Los-Reyes, C.; García, F.J.; Moreno, M.M.; Sánchez-Ormeño, M.; Higueras, P. Influence of the soil $\mathrm{pH}$ in the uptake and bioaccumulation of heavy metal ( $\mathrm{Fe}, \mathrm{Zn}, \mathrm{Cu}, \mathrm{Pb}$ and $\mathrm{Mn}$ ) and other elements ( $\mathrm{Ca}, \mathrm{K}, \mathrm{Al} \mathrm{Sr}$ and $\mathrm{Ba})$ in vine leaves, Castilla-La Mancha (Spain). J Geochem. Explor. 2017, 174, 79-83. [CrossRef]

18. Neuendorf, K.E.; Mehl, J.P., Jr.; Jackson, J. Glossary of Geology, 5th ed.; American Geological Institute: Alexandria, VA, USA, 2005; p. 799.

19. Schoeneberger, P.J.; Wysocki, D.A.; Benham, E.C.; Soil Survey Staff. Field Book for Describing and Sampling Soils, Version 3.0; Natural Resources Conservation Service, National Soil Survey Center: Lincoln, The Netherland, 2012; p. 298.

20. Kabata-Pendias, A. Trace Elements in Soils and Plants; CRC Press: Boca Raton, FL, USA, 2011.

21. Mertens, J.; Smolders, E. Zinc. In Heavy Metals in Soils. Environmental Pollution; Alloway, B., Ed.; Springer: Dordrecht, The Netherlands, 2013; Volume 22, pp. 283-311.

22. García-Escudero, E.; Martin, I. Apuntes sobre fertilización del viñedo. Cuad. Campo 2019, 62, 32-39.

23. White, R.E. Understanding Vineyard Soils, 2nd ed.; Oxford University Press: Oxford, UK, 2009; p. 280.

24. Adriano, D.C. Trace Elements in Terrestrial Environments: Biogeochemistry, Bioavailability, and Risks of Metals, 2nd ed.; Springer: Berlin/Heidelberg, Germany, 2001; p. 867. ISBN 978-0-387-21510-5.

25. Huzum, R.; Iancu, G.O.; Buzgar, N. Geochemical distribution of selected trace elements in vineyard soils from the Huşi area, Romania. Carpath. J. Earth Environ. Sci. 2012, 7, 61-70.

26. Peris, M.; Micó, C.; Recatalá, L.; Sánchez, J. Heavy metal contents in horticultural crops of a representative area of the European Mediterranean region. Sci. Total Environ. 2007, 378, 42-48. [CrossRef] 
27. Bora, F.D.; Bunea, C.L.; Rusu, T.; Pop, N. Vertical distribution and analysis of micro, macroelements and heavy metals in the system soil-grapevine-wine in vineyard from North-West Romania. Chem. Cent. J. 2015, 9, 19. [CrossRef]

28. Angelova, V.R.; Ivanov, A.S.; Braikov, D.M. Heavy metals ( $\mathrm{Pb}, \mathrm{Cu}, \mathrm{Zn}$ and $\mathrm{Cd}$ ) in the system soil-grapevine-grape. J. Sci. Food Agri. 1999, 79, 713-721. [CrossRef]

29. Iñigo, V.; Marin, A.; Andrades, M.; Jiménez-Ballesta, R. Evaluation of the Copper and Zinc Contents of Soils in the Vineyards of La Rioja (Spain). Environments 2020, 7, 55. [CrossRef]

30. Yamamoto, K.; Hashimoto, Y.; Kang, J.; Kobayashi, K. Speciation of phosphorus zinc and copper in soil and water-dispersible colloid affected by a long-term application of swine manure compost. Environ. Sci. Technol. 2018, 52, 13270-13278. [CrossRef] [PubMed]

31. Mirlean, N.; Roisenberg, A.; Chies, J.O. Metal contamination of vineyard soils in wet subtropics (southern Brazil). Environ. Polut. 2007, 149, 10-17. [CrossRef]

32. Sipos, P.; Németh, T.; Kis, V.K.; Mohai, I. Sorption of copper, zinc and lead on soil mineral phases. Chemosphere 2008, 73, 461-469. [CrossRef]

33. Manceau, A.; Lanson, B.; Schlegel, M.L.; Harge, J.C.; Musso, M.; Eybert-Berard, L.; Hazemann, J.L.; Chateigner, D.; Lamble, G.M. Quantitative Zn speciation in smelter-contaminated soils by EXAFS spectroscopy. Am. J. Sci. 2020, 300, 289-343. [CrossRef]

34. Jacquat, O.; Voegelin, A.; Kretzschmar, R. Local coordination of Zn in hydroxy-interlayered minerals and implications for Zn retention in soils. Geochim. Cosmochim. Acta 2009, 73, 348-363. [CrossRef]

35. ATDSR (United States Agency for Toxic Substances and Disease). Toxicological Profile for Zinc; U.S. Department of Health and Human Services: Atlanta, GA, USA, 2007; p. 352.

36. Ambrosini, V.G.; Rosa, D.J.; Prado, J.P.C.; Borghezan, M.; Melo, G.W.B.; Soares, J.J.; Comin, C.R.F.S.; Simao, D.G.; Brunetto, G. Plant Physiology and Biochemistry Reduction of copper phytotoxicity by liming: A study of the root anatomy of young vines (Vitis labrusca L.). Plant Physiol. Biochem. 2015, 96, 270-280. [CrossRef]

37. Zarco-Tejada, P.J.; Berjon, A.; López-Lozano, R.; Miller, J.R.; Martín, P.; Cachorro, V.; González, M.R.; Frutos, A. Assessing vineyard condition with hyperspectral indices: Leaf and canopy reflectance simulation in a row-structured discontinuous canopy. Remote Sens. Environ. 2005, 99, 271-287. [CrossRef]

38. Úbeda, X.; Francos, M.; Eguzkiza, P.; Stefanuto, E.B. Soil and grapevine leaf quality in organic vineyards of different ages in DO Rioja-Alavesa, northern Spain. Span. J. Soil Sci. 2021, 11, 6-21.

39. Johnson, L.F.; Roczen, D.E.; Youkhana, S.K.; Nemani, R.R.; Bosch, D.F. Mapping vineyard leaf area with multispectral satellite imagery. Comput. Electron. Agric. 2003, 38, 33-44. [CrossRef]

40. Chopin, E.I.B.; Marin, B.; Mkoungafoko, R.; Rigaux, A.; Hopgood, M.J.; Delannoy, E.; Cancès, B.; Laurain, M. Factors affecting the distribution and mobility of trace elements $(\mathrm{Cu}, \mathrm{Pb}, \mathrm{Zn})$ in a perennial grapevine (Vitis vinifera L.) in the Champagne region of France. Environ. Pollut. 2008, 156, 1092-1098. [CrossRef] [PubMed]

41. Vystavna, Y.; Rushenko, L.; Diadin, D.; Klymenko, O.; Klymenko, M. Trace metals in wine and vineyard environment in southern Ukraine. Food Chem. 2014, 146, 339-344. [CrossRef] [PubMed]

42. Amorós, J.A.; Pérez-de-los-Reyes, C.; García-Navarro, F.J.; Bravo, S.; Chacón, J.L.; Martínez, J.; Jiménez-Ballesta, R. Bioaccumulation of mineral elements in grapevine varieties cultivated in "La Mancha". J. Plant Nut. Soil Sci. 2013, 176, 843-850. [CrossRef]

43. Reiman, C.; Birke, M.; Demetriades, A.; Filzmoser, P.; O'Connor, P. Chemistry of Europe's Agricultural Soils, Part A and B; Schweizerbart Science Publishers: Stuttgart, Germany, 2014; p. 874. ISBN 9783510968480.

44. Amoros, J.A.; Bravo, S.; Perez-de-los-Reyes, C.; García-Navarro, F.J.; Campos, J.A.; Sanchez-Ormeño, M.; Jimenez-Ballesta, R.; Higueras, P. Iron uptake in vineyard soils and relationships with other elements (Zn, Mn and Ca). The case of Castilla-La Mancha, Central Spain. Appl. Geochem. 2018, 88, 17-22. [CrossRef] 